\title{
ENGLISH NATIONAL IDENTITY AND THE NATIONAL FOOTBALL TEAM: THE VIEWS OF CONTEMPORARY ENGLISH FANS
}

\begin{abstract}
The English St George Cross has recently become more prominent than the British Union Jack amongst English football fans. Some authors assume this to be evidence that a specifically English national consciousness is arising. However, the ways in which English fans describe their own national identity and their feelings towards the national football team have not been the primary focus of previous research. In order to explore this area further, online questionnaires were disseminated amongst various fan groups during the 2006 World Cup, the 2008 European Championships and the summer of 2009, gleaning a total of 1355 valid responses. Frequencies were calculated for answers to multiple-choice items and answers to open response items were categorized using a qualitative coding approach. Findings indicate that the relationship between English national identity and support for the national team is more complex than the increased display of the St George Cross suggests. Specifically English articulations of identity were not homogenous among English football fans: British, local and even European layers of identity were considered to be more important to some fans. Also, the relationship between English national identity and feeling represented by the national team was often dependent on their success. Finally, results signified a complex relationship between fans' support for their English club and their support for the England team, which was often related to club location.
\end{abstract}

\section{Introduction}

Developments in European integration mean citizens from individual nation-states within the European Union (EU) now feel the need to reassert their national, regional and/or local identities. [1] Such developments have led to debates surrounding competing articulations of 'national' identity within the United Kingdom of Great Britain and Northern Ireland (UK). Such debates have intensified since the 'Celtic' nations within the UK - Wales, Scotland and Northern Ireland - achieved varying levels of devolved political power in the late 1990s, yet England did not. [2] Together with the declining importance of the British Empire overseas over the latter half of the twentieth century, [3] these recent developments point towards a decline in widespread support for a 'British' identity within the UK. [4] The main focus of this paper will be on the extent to which football fandom can provide a lens through which the complexities underlying contemporary English national identity can be observed. According to Duke and Crolley:

Football captures the notion of an imagined community perfectly. It is easier to imagine the nation and confirm national identity, when eleven players are representing the nation in a match against another nation. [5]

Although it would be naive to argue that everyone who considers themselves English articulates their national identity through football, it is difficult to deny that football has long been considered England's national sport. [6] There is no other mainstream sport in which a national team have exclusively represented England (rather than Britain) in major international competitions, [7] and each of the home nations within the UK has always had separate national football teams and Football Associations. [8] 
A number of authors have deemed it prominent to comment on the rise in the use of the specifically English St George Cross at English football fixtures. For instance, Krishan Kumar suggests:

The recent flaunting by the English of the St George's Cross at football matches presumably indicates a rise in specifically English as opposed to British national consciousness - or at least recognition of the distinction between them. [9]

Also referring to the heightened use of the St George Cross, Anthony King suggested that we are witnessing the rise of an English national consciousness among football fans, which is a response to advancing processes of globalisation, European integration and devolution. [10] Moreover, Richard Weight states that the Euro 96 football tournament (hosted by England) helped transform it 'from a vile antithesis of a nation' into one 'trying to rediscover itself by synthesizing the cultural changes of the postwar years'. [11] Aughey contends that the number one hit song 'Football's Coming Home' symbolised the tournament being the first opportunity for the English to reassert themselves in a self-confident and agreeable way. [12]

It is also important to remember that English fan culture has been significantly impacted by the globalization of English club football since the early 1990s. [13] There have been fan responses specifically to the 'Europeanisation' of English club football by way of a noticeable rise in club over country debates from which the impact of European integration on top flight football can be clearly observed. [14] A rise in European consciousness amongst fans of top-flight Premier League clubs has sometimes resulted in a rejection of the England team and this was perhaps first noticed by King in his work on a core of Manchester United fans. [15]

Although the importance of studying English football fandom in relation to English national identity is highlighted by Robinson, she does not provide any empirical evidence (other than observations) to suggest that the heightened use of specifically English national symbols are demonstrated by fans to represent a unified English national consciousness. [16] Contrasting evidence from Abell, Condor, Lowe, Gibson and Stevenson suggests that English football fans' articulations of support for the national team do not even necessarily represent their wider feelings of national sentiment. [17] Although Abell et al interviewed a broad sample of English individuals, only some of them were actually football fans. Therefore, the aim of the current study was to provide firmer evidence from fans themselves.

\section{Methodology}

A questionnaire was designed to collect fans' opinions on the relationship between their English national identity and their feelings towards the national football team. The questionnaire contained a mixture of multiple-choice and open-response questions and was distributed to three different samples of English football fans on three different occasions: first, during the 2006 World Cup, in which England reached the quarter finals; second, during the 2008 European Football Championships (Euro 2008), for which England (as well as all the other home nations within the UK) failed to qualify; and finally, in the summer of 2009 when there were no significant international football tournaments occurring. This design was chosen in order to determine whether success and/or involvement of the England team in a major international football tournament had any impact on answers given by fans. The frequencies for the multiple-choice answers were calculated and the answers to the open response questions were coded using a qualitative approach so that data from the different samples could be compared. [18]

The questionnaire was distributed online via various discussion forums, email loops 
and websites for football fans. The latter included the Football Supporters' Federation (FSF) and the Football Fan Census (FFC). Inclusion criteria were that respondents had to be fans of an English club and/or the English national team and they had to have defined their national identity as either English or British (those who defined themselves as Welsh, Scottish, Northern Irish or Irish were not included in the sample). Although a total of 1355 valid responses were obtained across the three samples, each sample varied significantly in size. The 2006 World Cup survey gleaned 352; the Euro 2008 survey gleaned 127; and, the summer 2009 survey gleaned 876 valid responses.

The audience for football in England is still predominantly male and this was reflected in the composition of the three samples obtained. Women currently make up $15-20 \%$ of football crowds, [19] and similar percentages of female respondents made up each of the three samples obtained in the current study: 18\% for the World Cup 2006 sample; 9\% for the Euro 2008 sample; and, 12\% for the summer 2009 sample. The mean age of respondents in each sample was: 33 years in World Cup 2006; 32 years in Euro 2008; and, 40 years summer 2009.

In previous Internet-based studies on football fans some researchers have posted questionnaires on existing websites, whereas others have examined the online correspondence of fans on various sites. [20] In such studies the authors know little about their respondents. Markham suggests that this is still a problem for the contextualisation of results even when demographic information is collected online. [21] However, as Sapsford points out: 'Validity is probably not an issue. There is no reason to suppose that people are any more likely to misrepresent themselves on email or Internet questionnaires than on postal ones'. [22] Also online questionnaires have been reported to not only be easier and faster to distribute, but to glean faster/better response/completion rates and to contain less missing responses than postal ones. [23] It is for these reasons that online questionnaires were chosen as the data collection tool for this study.

\section{Fans' descriptions of their nationality}

Fans were asked: 'How would you personally describe your nationality?' This question was open-response so fans had to provide their own answers which were subsequently coded. Responses to this question were almost identical across the three different samples. As can be observed in Figure 1, the majority of fans, around $60 \%$, across all three samples described their nationality as 'English' and this correlates well with the findings from British Social Attitudes Surveys since the late 1990s which suggest that the English have responded to Welsh and Scottish devolution by choosing to define themselves as specifically English instead of British. [24] The confusion of British and English has been traditional throughout history and it is something the English have not had to think about until recently. [25]

However, around $30 \%$ of fans in each sample chose to define themselves as 'British'. Again, evidence from recent British Social Attitudes Surveys indicates there is still support for the idea of an all encompassing UK identity among a minority of English people, despite devolution of the 'Celtic' nations. [26] In addition, Bryant urges that because the British state is becoming increasingly less associated with the nations that make it up, Britain could now be regarded as a 'fifth nation' after England, Scotland, Wales and Northern Ireland. [27] The evidence provided here certainly adds weight to such an idea along with the fact that most of the respondents who have been categorized as having 'mixed' nationalities defined themselves as 'English/British' or even 'English or British' which may reflect an ongoing confusion between how to best define English nationality in the twenty-first century: 
Englishness and Britishness are identities in crisis. These 'national' identities have an ongoing confusion as to their relationships to themselves - where does Englishness stop and Britishness begin? In addition they have lost their former moorings in empire and have to reposition themselves in terms of evolving relations with Europe and with the national identities of the Irish, Welsh and Scottish as well as with postcolonial relations. [28]

Curtice states that the proportion of English respondents in British Social Attitudes Surveys who stated they are 'very proud' of their English locality (meaning city, county or region within England) has remained at one in four since 2001. [29] Although the proportion was nowhere near as high as this in the current survey, a small amount of respondents chose to describe their nationality in terms of their locality within England (termed 'Local' in Figure 1) - for example 'Scouse' or 'Yorkshireman'. Many have suggested local identities have been stronger for the English than any overriding sense of Englishness. The Scots, Welsh and Irish have seen themselves in contradistinction to the English and have based their national identities upon a 'Celtic non-Englishness'. Yet for the English, local identities often appear stronger than a homogenous sense of Englishness. [30] Borrowing Benedict Anderson's term for nations as 'imagined communities', Colls and Lancaster suggest that, 'regions, no less than nations, are imagined communities'. [31] For instance, the north-south regional divide in England is associated with a number of images and stereotypes which illustrate very different conceptions of Englishness, mainly based around assumed social class divisions between the 'northern working class' and the 'southern political elite'. [32]

Finally, in the 'other' category were a mixture of responses from fans, some describing themselves as having 'global' identities, for instance 'citizen of the world', and others who chose to define their nationality as 'European'. Writing in the late 1980s, Norbert Elias recognised that the function of the effective survival unit has been visibly shifting more and more from the level of nation-states to the post-national unions of states (such as the European Union) and beyond them to humanity. [33] Indeed, according to Laffan, O'Donnell and Smith, legal, political and popular aspects of sovereignty for EU member states have certainly been questioned by advancing processes of European integration. [34]

According to Aughey there are four main interrelated states of anxiety for the English today: absence, silence, anticipation and imitation. [35] Considering the variety of articulations of national identity provided by fans across the three samples presented in the current study, Aughey's anxiety of anticipation is perhaps most applicable:

The anticipation in this case is not the end of empire but the end of the United Kingdom or the anxiety that, while the other nations are coming out from under the 'safety blanket' of Britishness, the English will be smothered under its folds...The confusion of English and British is no longer just a failure to acknowledge the properties of nomenclature in a multinational Union, but a failure to acknowledge the world the English are now in. [36] 


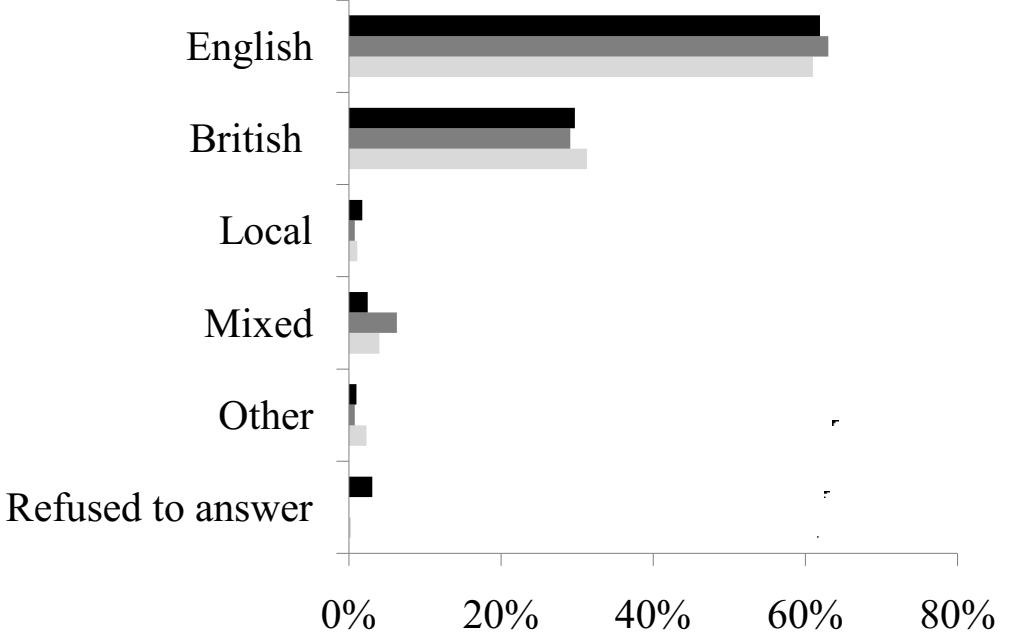

Figure 1. Categories of nationality.

Note: black represents 'Summer 2009'; dark grey represents 'Euro 2008'; and, light grey represents 'World Cup 2006'.

In the following section these varied articulations of English national identity are discussed in relation to whether or not fans felt represented by the English national team.

\section{Feeling represented by the England team and nationality}

Fans were asked: 'Do you feel that the English national football team represents you in any way?' Fans could either choose to answer 'yes' or 'no' to this question, and the following item in the questionnaire invited them to explain their answer. As can be seen in Figure 2, the majority of respondents answered 'yes' during the 2006 World Cup, in which England reached the quarter finals. The fact that the England team did not qualify for the Euro 2008 tournament seems to have had the opposite effect, with the majority of fans not feeling represented by the team. Yet, there was not as much of a difference between 'yes' and 'no' answers as there was in the World Cup 2006 sample, with just under half (47\%) still stating that they felt the team represented them. So perhaps fans' views were not entirely shaped by the England team's lack of qualification. Answers to this question swung the other way for the summer 2009 sample with just over half (57\%) stating that the England team represented them, but still a large proportion (43\%) stating that they did not feel represented.

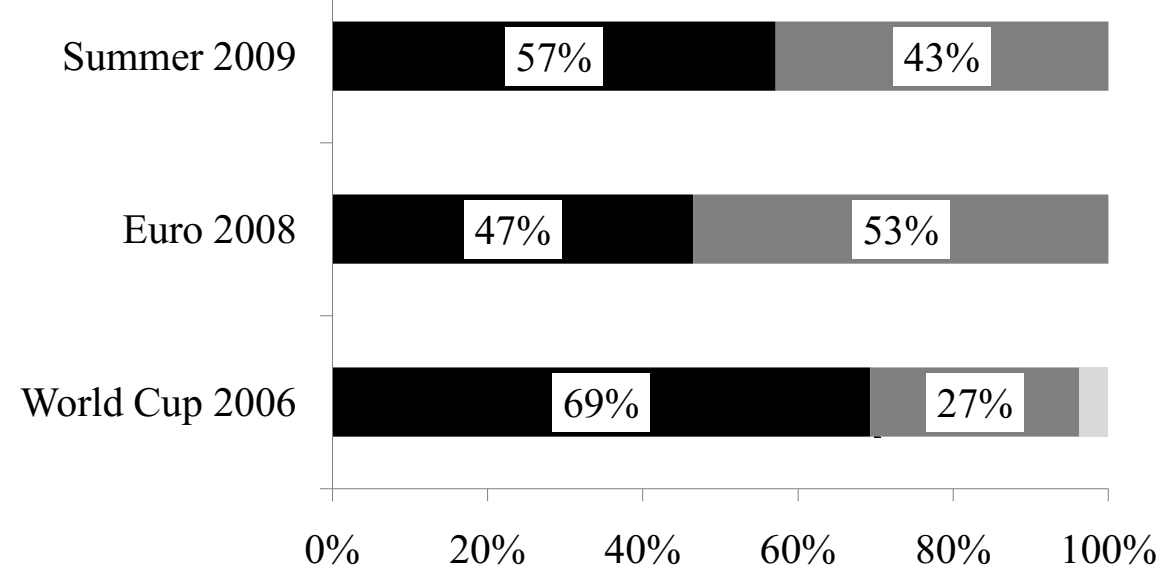

Figure 2. Feeling represented by the national team.

Note: black represents 'yes'; dark grey represents 'no'; light grey represents 'no answer'. 
Responses to the feeling represented question were compared with answers to the nationality question. [37] In the World Cup 2006 sample (Figure 3.), the majority in all categories of nationality answered 'yes' they did feel represented by the England team, although there was a 50/50 split between 'yes' and 'no' answers in the 'local' category. The highest percentage of respondents in the largest nationality category, 'English', did feel represented by the England team. This provides further evidence that the England team's successful run in the 2006 World Cup tournament led to fans articulating an association with the team.

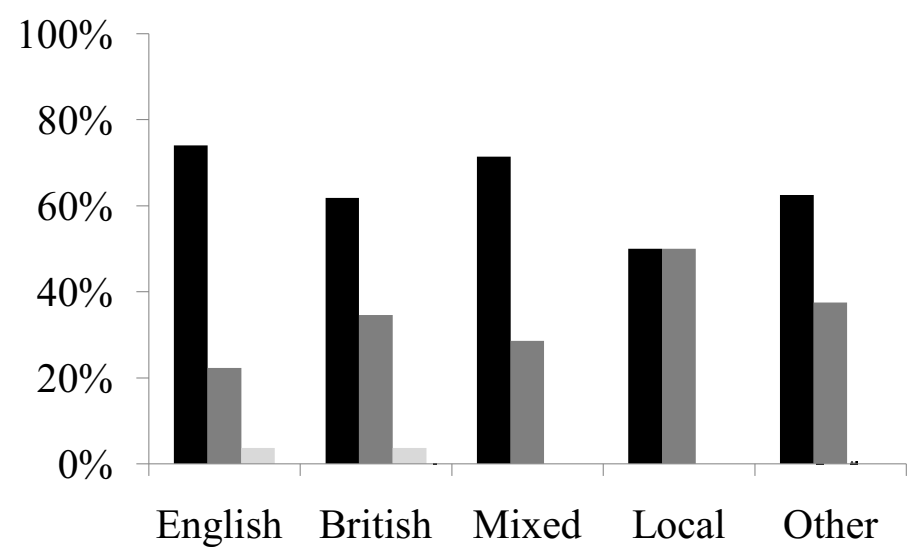

Figure 3. Nationality and feeling represented by the England team during World Cup 2006.

Note: black represents 'yes'; dark grey represents 'no'; light grey represents 'no answer'.

In the Euro 2008 sample (Figure 4.), although answers were divided quite evenly between 'yes' and 'no', within the largest nationality categories ('English' and 'British') feelings of not being represented by the England team were highest, which contrasts with the findings from the World Cup 2006 sample. In fact, the only nationality category in this sample within which the majority of fans felt represented by the England team was the 'mixed' nationality category. This therefore provides further evidence to suggest that England's failure to qualify for the Euro 2008 tournament led to fans feeling unrepresented by the team.

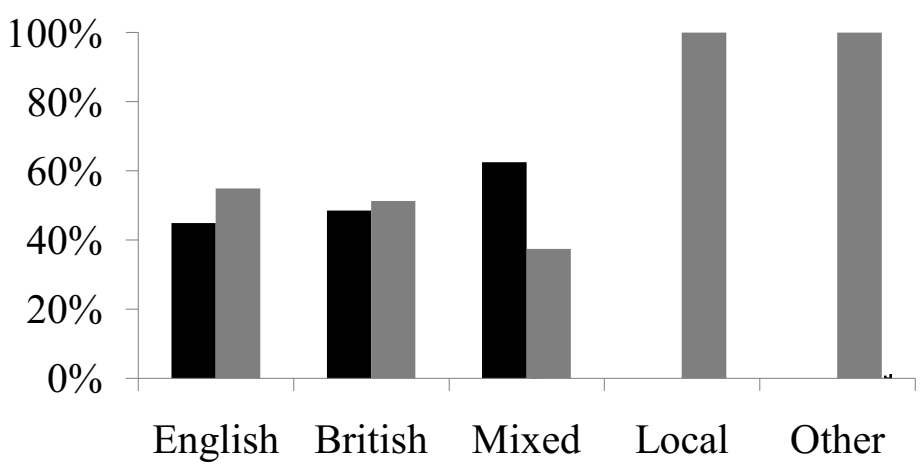

Figure 4. Nationality and feeling represented by the England team during Euro 2008.

Note: black represents 'yes'; dark grey represents 'no'.

Finally, in the summer 2009 sample (Figure 5.), fans in most nationality categories felt represented by the England team, except for within the 'British' category where an overwhelming $96 \%$ of respondents answered that they did not feel represented. This seems 
somewhat of an anomaly both amongst the other categories within this sample and if compared to those in the other samples.

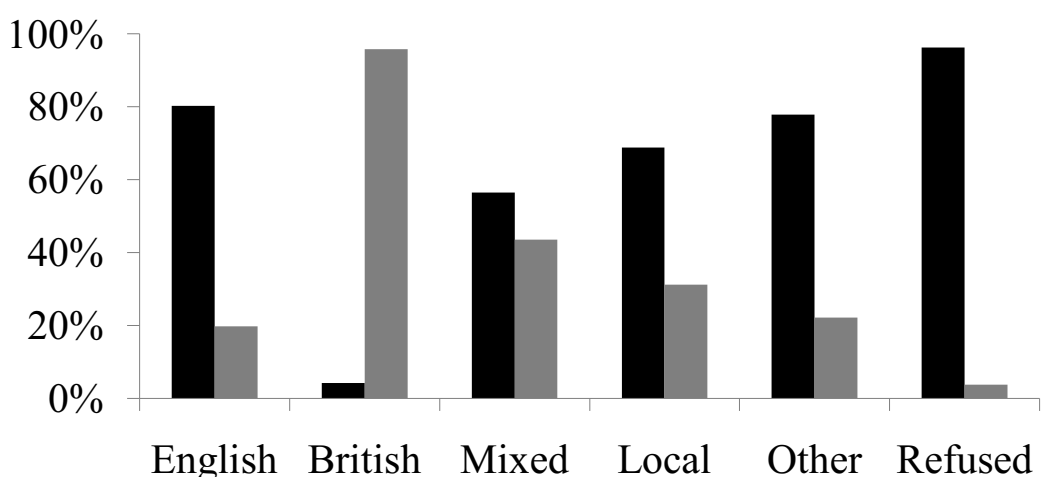

Figure 5. Nationality and feeling represented by the England team during summer 2009.

Note: black represents 'yes'; dark grey represents 'no'.

Overall, it seems that describing oneself as specifically 'English' rather than 'British' means fans were more likely to feel represented by the England national team, except for during Euro 2008, a tournament for which they did not qualify. This suggests that the relationship between English national identity and feeling represented by the team was dependent on their success, even amongst fans who described their nationality as specifically 'English'. This evidence adds some weight to that provided by Abell et al who suggested that support for the national team is not necessarily strongly associated with feelings of English national sentiment. [38]

\section{Fans' explanations regarding feeling represented by the England national team}

Respondents were asked to explain their reasons for choosing either 'yes' or 'no' in response to the question 'Do you feel that the English national football team represents you in any way?' These responses were coded into different themes depending on whether the answer was 'yes' or 'no'. Seven themes were identified relating to the 'yes' answers and six themes for the 'no' answers. In the following sub-sections the two most popular codes for both the 'yes' and 'no' answers in each of the three samples are discussed.

\section{World Cup 2006}

Amongst the $69 \%$ of fans who stated that the England team represented them, the majority (41\%) referred to the team reflecting England or Englishness specifically in some way. For instance one fan stated: 'Gives individual attention to England as opposed to UK/Great Britain etc. Not able to express patriotism in any other way.' Such sentiments reinforce what Robinson states about the sphere of football being the place where a specific English, rather than British, national identity can be proudly displayed. [39] The second largest category amongst those who answered 'yes' was made up of 13\% of fans who stated that the England team represented values that they felt were national characteristics. For instance one fan explained: 'grit....determination...things I associate with being English'. Other examples included the terms 'passion', 'spirit' and 'pride'. These are the kinds of characteristics often drawn upon by the national press to represent Englishness when the England team are involved in international tournaments. [40] 
Amongst the $27 \%$ of fans who answered 'no', they did not feel the England team represented them, the majority (30\%) stated that they either disliked or could not relate to the players, the manager and/or the FA. Here most fans referred to the players' lavish lifestyles being far removed from those of ordinary fans as well as the wider English population. For instance, one fan stated: 'The team (11 highly-paid morons) are only representing themselves; it is a sheer coincidence that they were born in the same country as me'. The second largest category amongst those who answered 'no' was comprised of $24 \%$ of fans who felt the national team did not represent them personally at all. These fans either referred to the team representing the sport of football in England alone or the political image of the nation overseas, but in no way the people of the nation. For instance one fan stated: 'They are a football team and represent the sport of the country not the people'. This is very similar to what was found in interview-based research conducted by Abell et al, who reported that:

The overwhelming majority of respondents either distinguished their support for the national football team from connotations of general patriotic sentiment, or else sought to distinguish their claims to national pride from connotations of English football support. [41]

However, the difference with the current findings is that fans with such views were not in the majority as they seemed to be in the interviews conducted by Abell at al. This may be due to the fact that Abell et al's sample were not predominantly football fans, whereas those in the current study were.

\section{Euro 2008}

The proportion of fans who felt the England team represented them, made up less than half (47\%) of the Euro 2008 sample and this contrasts to the $69 \%$ majority who chose this answer during World Cup 2006. Nevertheless, as in the World Cup 2006 sample, the majority (63\%) of fans in the Euro 2008 sample who answered 'yes' cited the reason as being because the team directly represented their English national identity. However, a number of respondents also mentioned the significance of their support for their English club team over their support for England. For instance one fan stated: 'It is not as important as my club team, but I am English and proud to be so. However, I think it was better when England travelled the UK playing their home matches rather than being in London'. In fact, many other fans were keen to mention that the England team were more representative of the English nation when they were forced to travel around the country whilst Wembley stadium was being rebuilt. It was particularly fans from more northern areas of the country (farthest away from the London capital) who asserted this viewpoint.

Much of the historical literature on sport and Englishness has tended to focus on 'the north' as having an identity that contrasts to that of 'the south'. [42] According to Huggins: 'Sport...has drawn upon and reinforced prevailing perceptions of the North as being different from the South'. [43] Phelps has attempted to show that the image of northern sport depicted by many sports historians is nothing more than a stereotype and does not equate with evidence. [44] More recently, Stone has added some support to Phelps' claim through a survey conducted in 2002 comparing the views of Surrey and Yorkshire county cricket fans. Findings suggested that both sets of northern and southern English fans could not be separated by a north-south divide. [45]

The second largest proportion (14\%) of fans amongst those who answered 'yes' fell into the category of suggesting the England team were representative of the nation, but not of them personally. For example, one fan clarified: 'Yes, but only slightly and certainly not 
personally. Our nation is a largely artificial construct and they just happen to be the national team of our country's national sport'. This is interesting considering this theme was the second largest amongst those who answered 'no' to the same question during World Cup 2006.

Out of the 53\% majority who stated they did not feel represented by the national team, the majority of fans $(65 \%)$ stated that they either disliked or could not relate to the players, the manager and/or the English FA. As in the World Cup 2006 sample, the luxury lifestyles of the players was usually the main explanation given, for example: 'Do not 'like' many of the players playing at that level at all. They're paid so much and live completely different lifestyles, so hardly represent the country'. However, in contrast to the World Cup 2006 sample, the second largest theme here was comprised of fans who were blatant about the England team not meaning half as much to them as their club. Many also referred to the England team representing a southern English or even specifically London-based identity that people in other regions of the country did not associate with, for instance: 'Not interested in the national team. Most people up North support their club not England. It's picked by the southern based media and doesn't interest me'. These findings about the primacy of club over country support reinforce the arguments made by King regarding the 'post-national' identity of a core of Manchester United fans in terms of their strong associations with the locale of Manchester instead of with the nation. [46]

\section{Summer 2009}

In contrast to the Euro 2008 sample, the majority (57\%) in summer 2009 answered 'yes', they felt the England team represented them, although this was not as much of a majority as in the World Cup 2006 sample. As with the previous two samples, the largest category amongst fans who answered 'yes' was made up of those who referred to the team standing for England or Englishness specifically (47\%). Many fans again referred to there being few places other than football where a specifically English, as opposed to British, identity could be articulated. According to one fan: 'It's the only time we can get behind the flag and be English, in this PC world'. Others who fell into this category were keen to make it as explicit as possible that the England team represented their English national identity. For instance one fan boasted: 'I'm a patriot and I'm born and bred in Doncaster, the first town in the country to adopt the St Georges cross and dedicate its church to St George!'

As in the Euro 2008 sample, the second highest category (12\%) for those who answered 'yes' referred to the national team not representing them personally or even primarily. Again, a number of fans suggested that the England team represented London or the south of England only. For instance, one fan explained: 'Only in so far as the team is England and I am English, however as I live in the North I feel disenfranchised from the National team, which as far as I can see is only meant for Londoners'. Some fans also mentioned that the name 'England' simply distinguishes the football team from other national teams and is a hollow concept as far as representing an identity is concerned.

As with the previous two samples, the majority (43\%) of respondents who did not feel represented by the England team, gave their reasons as being that they could not relate to or disliked the team's players, manager or the FA. Some fans mentioned the choice of the FA to continue to use the British national anthem 'God Save the Queen' instead of a more specifically English one, despite the fact that the other home nations within the UK have had their own anthems for years. For instance, one fan asserted: 'I have no affiliation with any of the players and also feel that using the union anthem instead of having an English anthem as Scotland, Wales etc do is not representative of the English fans'. The fact that England has 
few non-British traits has been mooted by a number of authors in the past. For instance, Robinson suggests:

England has no distinctive political manifestation (Parliament is British), it has no national dress, no national anthem and even its patron Saint is neither English nor uniquely its own. The English (as opposed to the British) have few of the cultural or political trappings that have come to be associated with the nation. [47]

Moreover, Jeff Hill contended: 'English identity is the least precise of all the domestic nationalisms. There is no direct equivalent of 'Scotland the Brave' or 'Cwm Rhondda'. [48]

As witnessed within the Euro 2008 sample responses, the second largest category $(23 \%)$ of reasons for fans not feeling represented by the national team in summer 2009 was again related to the primacy of club football over international football. For instance one fan went as far as saying: 'My only feelings towards England are worries that Liverpool players will be injured while playing. I would rather no Liverpool players were selected'. Again the north-south divide was implied by a number of these fans. For instance: 'It is very hard to get tickets and you always have to go to Wembley. They should move around a bit and play at Newcastle and Manchester; it would give fans up north a chance to see them. I am sick of everything being in London'.

In light of the large number of responses that focussed on the primacy of club football over international football across all three samples, location of club supported was compared to participants' responses to the feeling represented by the England team question. As can be observed in Figure 6, clubs in all nine English regions were represented in every sample. [49] With regards to the relationship between locations of clubs supported by fans feeling represented by the England team, there were some interesting results which appear to contrast with the sentiments expressed in some of the qualitative answers provided above.

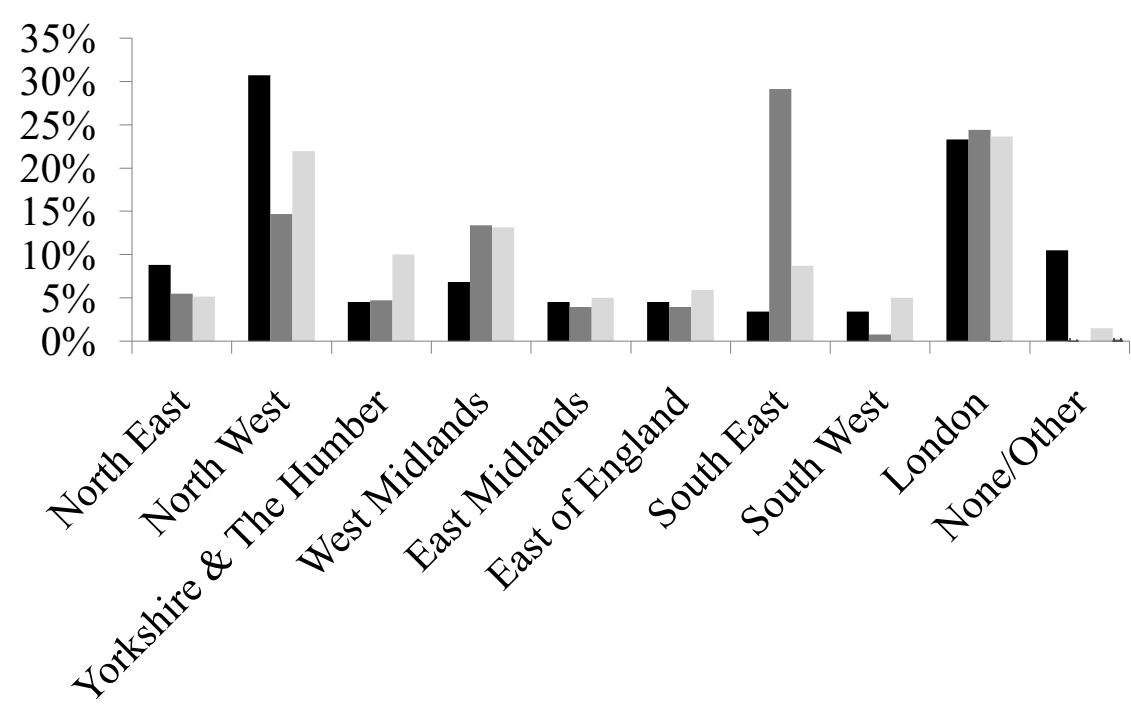

Figure 6. Location of clubs supported.

Note: black represents 'World Cup 2006'; dark grey represents 'Euro 2008'; and, light grey represents 'summer 2009'.

During World Cup 2006 the majority of fans supporting clubs in all regions did feel represented by the England team. The largest of these majorities was surprisingly in Yorkshire \& the Humber (94\%) and the lowest of these was in the east midlands $(56 \%)$. However, during the Euro 2008 competition, the only majorities of fans who stated they felt 
represented by the England team were those of clubs situated in the south east $(62 \%)$ and east midlands $(60 \%)$. The most evenly distributed answers can be found in the summer 2009 sample, where those who answered 'yes' were always in the majority as in the World Cup 2006 sample, but not by as much. The largest majority was in the south west (73\%) and the lowest in the north west (53\%) and south east (53\%).

Across all three samples there was little support for the notion that fans of clubs in northern English regions furthest away from London felt less represented by the England team than those of clubs in the southern regions nearer to and in London. In addition, it seemed that success of the England team had a large bearing on whether fans from all English regions felt represented by the national team.

\section{Conclusion}

One of the key findings from this research study is that specifically English articulations of identity were not homogenous among English football fans. No dramatic alterations in definitions of national identity were observed over the time period studied (2006-2009). Around $60 \%$ from each of the three samples defined their national identity as English and approximately $30 \%$ as British. Local and even European layers of identity were considered to be more important to some, albeit a minority, of fans. Also, the relationship between English national identity and feeling represented by the national team was dependent on their success, even amongst fans who described their nationality as specifically 'English'. Results also signified a complex relationship between fans' support for their English club and their support for the England team, which was often related to the location of their club. Although a number of qualitative responses indicated fans of northern based clubs tended to feel less represented by the England team than those of southern based teams closer to London, this was not supported by comparing locations of clubs the fans supported with frequencies of 'yes' and 'no' responses to the feeling represented by the England team question. The question of club versus national preferences in England adds further complexity to the already multifaceted relationship between football and English national identity. As such, this area requires much further investigation.

In sum, findings indicate that the relationship between English national identity and support for the national team is more complex than the increased display of the St George Cross suggests. Elias recognised that people in contemporary European nation-states have multiple identities that are pluralized or even multi-layered - they are local, regional, national, and global. [50] It is these overlapping affiliations that form the flexible and complex network of the 'habitus' of a person. Thus, instead of viewing a person's identity as fixed and immovable, it is perhaps more appropriate to view identity as a process that may be subject to change. These findings partially reinforce the work of Abell et al and help challenge common-sense notions that the increased display of specifically English symbols marks the beginnings of a unified English national project that will follow the path of the other now devolved nations within the UK. [51] The influence of football on articulations of Scottish, Welsh and Northern Irish identity may have become less significant since Euro 96 due to the lack of success of their national sides. However, this is speculation only and is an area that perhaps requires further research.

Whilst the findings reported above may not be representative of all English football fans, let alone all English people, they do provide a deeper insight into complexities underlying the relationship between football fandom and English national identity. Future studies in this area can hopefully utilise the evidence provided here to help further explore whether any links can continue to be made between the actions of football fans and the multifaceted concept of English national identity. 
Notes

[1] Roche, Exploring the Sociology of Europe.

[2] Bryant, 'These Englands, or where does devolution leave the English?'; Bryant, The Nations of Britain; O'Neill, 'Unfinished business: the 'significant others'.

[3] Hobsbawm, Age of Extremes: The Short Twentieth Century, 1914-1991.

[4] Curtice, 'Is there an English backlash? Reactions to devolution', 5.

[5] Duke and Crolley, Football, Nationality and the State, 4.

[6] Porter, "Your boys took one hell of a beating!'; Russell, Football and the English.

[7] Robinson, 'Tackling the anxieties of the English: searching for the nation through football'.

[8] Moorhouse, 'One State, Several Countries: Soccer and Nationality in a 'United Kingdom";

[9] Kumar, The Making of English National Identity, $275 n$.

[10] King, 'Nationalism and Sport', 253.

[11] Weight, Patriots: National Identity in Britain 1940-2000, 26.

[12] Aughey, The Politics of Englishness.

[13] Hamil, Michie, Oughton and Warby, Football in the Digital Age.

[14] Giulianotti and Robertson, Globalization \& Football, 107; Levermore and Millward, 'Official policies and informal transversal networks: Creating 'pan-European identifications' through sport?'; Millward, 'We've all got the bug for Euro-Aways': what fans say about European Football Club Competition'.

[15] King, 'Football fandom and post-national identity in the new Europe'; King, The European Ritual: Football in the New Europe.

[16] Robinson, 'Tackling the anxieties of the English', 221.

[17] Abell, Condor, Lowe, Gibson and Stevenson, 'Who ate all the pride? Patriotic sentiment and English football support', 113.

[18] Miles and Huberman, Qualitative Data Analysis, 56.

[19] Jones, 'Female Fandom: Identity, Sexism, and Men's Professional Football in England'.

[20] Johnes, “We Hate England! We Hate England?' National identity and antiEnglishness in Welsh soccer fan culture'; Ruddock, 'Lets Kick Racism out of football'; Wilson, 'All together now, 'click'.

[21] Markham, 'The methods, politics, and ethics of representation in online ethnography'.

[22] Sapsford, 'Research and information on the net', 129.

[23] Lonsdale, Hodge and Rose, 'Pixels vs. paper: Comparing online and traditional survey methods in sports psychology'.

[24] Curtice, 'Is there an English backlash? Reactions to devolution'; Bryant, The Nations of Britain; Bryant, 'These Englands, or where does devolution leave the English?'

[25] Kumar, The Making of English National Identity.

[26] Curtice, 'Is there an English backlash? Reactions to devolution'.

[27] Bryant, The Nations of Britain.

[28] Byrne, 'England - whose England? Narratives of nostalgia, emptiness and evasion in imaginations of national identity', 510.

[29] Curtice, 'Is there an English backlash?', 7.

[30] Bryant, The Nations of Britain; Colls, Identity of England; Russell, Looking North: Northern England and the national imagination.

[31] Anderson, Imagined Communities: Reflections on the Origins and Spread of Nationalism; Colls and Lancaster, '1992 Preface', xiv. 
[32] Shields, Places on the Margin: Alternative Geographies of Modernity.

[33] Elias, The Society of Individuals, 218.

[34] Laffan, O'Donnell and Smith, Europe's Experimental Union: Rethinking Integration.

[35] Aughey, The Politics of Englishness, 93.

[36] Ibid., 97.

[37] Whilst reading Figures 3, 4 and 5 it is important to remember that the 'English' and 'British' nationality categories are by far the largest, made up by approximately $60 \%$ and $30 \%$ of respondents respectively, thus consisting of approximately $90 \%$ of all the responses in each sample.

[38] Abell et al, 'Who ate all the pride?'

[39] Robinson, 'Tackling the anxieties of the English'.

[40] Crolley and Hand, Football and European Identity: Historical Narratives through the Press; Crolley and Hand, Football, Europe and the Press.

[41] Abell et al, 'Who ate all the pride?', 104.

[42] Hill and Williams, Sport and Identity in the North of England.

[43] Huggins, 'Sport and the social construction of identity in north east England, 1800 1914', 132.

[44] Phelps, 'The Southern Football Hero and the Shaping of Local and Regional identity in the south of England'.

[45] Stone, 'Cricket's regional identities: the development of cricket and identity in Yorkshire and Surrey'.

[46] King, 'Football fandom and post-national identity in the new Europe'; King, The European Ritual.

[47] Robinson, 'Tackling the anxieties of the English', 221.

[48] Hill, 'Cocks, cats, caps and cups: A semiotic approach to sport and national identity', 16.

[49] The nine English regions are: North East, North West, Yorkshire \& The Humber, East Midlands, West Midlands, East of England, South East, South West, and London (Government Offices for the English Regions, available at http://www.gos.gov.uk/national/).

[50] Elias, The Society of Individuals.

[51] Abell et al, 'Who ate all the pride?'

\section{References}

Abell, J., Condor, S., Lowe, R. D., Gibson, S. and Stevenson, C. 'Who ate all the pride? Patriotic sentiment and English football support'. Nations and Nationalism, 13, 1, (2007): 97-116.

Anderson, B. Imagined Communities: Reflections on the Origins and Spread of Nationalism. London: Verso, 1991.

Aughey, A. The Politics of Englishness. Manchester: Manchester University Press, 2007.

Bryant, C. G. A. The Nations of Britain. Oxford: Oxford University Press, 2006.

Bryant, C. G. A. 'These Englands, or where does devolution leave the English?' Nations and Nationalism, 9, 3 (2003): 393-412.

Byrne, B. 'England - whose England? Narratives of nostalgia, emptiness and evasion in imaginations of national identity'. The Sociological Review, 55, 3 (2007): 509-530.

Colls, R. and Lancaster, B. '1992 Preface'. In R. Colls and B. Lancaster (eds.) Geordies: Roots of Regionalism (Second edition). Newcastle: Northumbria University Press, 2005: xi-xviii.

Colls, R. Identity of England. Oxon: Oxford University Press, 2002. 
Crolley, L. and Hand, D. Football and European Identity: Historical Narratives through the Press. London: Routledge, 2006.

Crolley, L. and Hand, D. Football, Europe and the Press. London: Routledge, 2002.

Curtice, J. 'Is there an English backlash? Reactions to devolution'. In A. Park, J. Curtice, K. Thomson, M. Phillips and E. Clery (eds.) British Social Attitudes: the $25^{\text {th }}$ Report. London: Sage, 2009: 1-23.

Duke, V. and Crolley, L. Football, Nationality and the State. London: Addison Wesley Longman, 1996.

Elias, N. The Society of Individuals. Oxford: Basil Blackwell, 1991.

Giulianotti, R. and Robertson, R. Globalization \& Football. London: Sage, 2009.

Hamil, S., Michie, J., Oughton, C. \& Warby, S. (Eds.). Football in the Digital Age: Whose Game is it Anyway? London: Mainstream Publishing, 1998.

Hill, J. 'Cocks, cats, caps and cups: A semiotic approach to sport and national identity'. Sport in Society, 2, 2 (1999): 1-21.

Hill, J. and Williams, J. (eds.) Sport and Identity in the North of England. Keele: Keele University Press, 1996.

Hobsbawm, E. Age of Extremes: The Short Twentieth Century, 1914-1991. London: Abacus, 1995.

Huggins, M. 'Sport and the social construction of identity in north east England, 1800 1914'. In N. Kirk (ed.) Northern Identities, Historical Interpretations of 'The North' and 'Northernness'. Aldershot: Ashgate, 2000: 132-162.

Johnes, M. ' We Hate England! We Hate England?' National Identity and Anti-Englishness in Welsh Soccer Fan Culture'. Cycnos, 25, 2 (2008): 143-157.

Jones, K. W. 'Female Fandom: Identity, Sexism, and Men's Professional Football in England'. Sociology of Sport Journal, 25, 4, (2008): 516-537.

King, A. 'Football fandom and post-national identity in the new Europe'. British Journal of Sociology, 51, 3 (2000): 419-442.

King, A. 'Nationalism and Sport'. In G. Delanty and K. Kumar (Eds.) The Sage Handbook of Nations and Nationalism. London: Sage, 2006: 249-259.

King, A. The European Ritual: Football in the New Europe. Aldershot: Ashgate, 2003.

Kumar, K. The Making of English National Identity. Cambridge: Cambridge University Press, 2003.

Laffan, B., O'Donnell, R. and Smith, M. Europe's Experimental Union: Rethinking Integration. London: Routledge, 2000.

Levermore, R. and Millward, P. 'Official policies and informal transversal networks: Creating 'pan-European identifications' through sport?' The Sociological Review, 55, 1 (2007): 144-164.

Lonsdale, C., Hodge, K. and Rose, E. K. 'Pixels vs. paper: Comparing online and traditional survey methods in sports psychology'. Journal of Sport \& Exercise Psychology, 28, (2006): 100-108.

Markham, A. N. 'The methods, politics, and ethics of representation in online ethnography'. In N. K. Denzin and Y. S. Lincoln (Eds.). The Sage Handbook of Qualitative Research (Third Edition). London: Sage, 2005: 793-820.

Miles, M. and Huberman, A. Qualitative Data Analysis. Thousand Oaks, CA: Sage, 1994.

Millward, P. 'We've all got the bug for Euro-Aways': what fans say about European Football Club Competition'. International Review for the Sociology of Sport, 41, 3/4 (2006): 375-393.

Moorhouse, H.F. 'One State, Several Countries: Soccer and Nationality in a 'United Kingdom', In J.A. Mangan (Ed.). Tribal Identities: Nationalism, Europe, Sport. London: Frank Cass, 1996: 55-74. 
O’Neill, M. 'Unfinished business: the 'significant others'. In M. O'Neill (Ed.). Devolution and British Politics. Harlow: Pearson, 2004: 333-352.

Phelps, N. 'The Southern Football Hero and the Shaping of Local and Regional identity in the south of England'. Soccer and Society, 2, 3 (2001): 44-57.

Porter, D. 'YYour boys took one hell of a beating!' English football and British decline, c. 1950-80'. In A. Smith and D. Porter, (Eds.). Sport and National Identity in the Postwar World. London: Routledge, 2004: 31-51.

Robinson, J. S. R. 'Tackling the anxieties of the English: searching for the nation through football'. Soccer \& Society, 9, 2 (2008): 215-230.

Roche, M. Exploring the Sociology of Europe. London: Sage, 2010.

Ruddock. A. 'Lets Kick Racism out of football - and the lefties too! Responses to Lee Bowyer on a West Ham web site'. Journal of Sport and Social Issues, 9, 4 (2005): 369-385.

Russell, D. Football and the English: A Social History of Association Football, 1863-1995. Preston: Carnegie, 1997.

Russell, D. Looking North: Northern England and the national imagination. Manchester: Manchester University Press, 2004.

Sapsford, R. 'Research and information on the net'. In R. Sapsford and V. Jupp, (Eds.). Data Collection and Analysis (Second edition). London: Sage, 2006: 124-136.

Shields, R. Places on the Margin: Alternative Geographies of Modernity. London: Routledge, 1991.

Stone, D. 'Cricket's regional identities: the development of cricket and identity in Yorkshire and Surrey'. Sport in Society, 11, 5 (2008): 501-516.

Weight, R. Patriots: National Identity in Britain 1940-2000. London: MacMillan, 2002.

Wilson, W. 'All together now, 'click': MLS soccer fans in cyberspace'. Soccer and Society, 8, 2/3 (2007): 381-398. 